\title{
PELATIHAN ANALISIS USAHA BUMDESA DESA BANJARSARI KABUPATEN PURWOREJO
}

\author{
Dwi Irawati ${ }^{1)}$, Dyah Panuntun Utami ${ }^{2)}$, Fitri Rahmawati') \\ 1)Program Studi Manajemen, Fakultas Ekonomi, Universitas Muhammadiyah Purworejo, \\ Jawa Tengah, Indonesia \\ 2)Program Studi Agribisnis, Fakultas Pertanian, Universitas Muhammadiyah Purworejo, \\ Jawa Tengah, Indonesia \\ Corresponding author: Dwi Irawati \\ email: dwi.irawati@umpwr.ac.id
}

\section{Diterima 27 November 2021, Direvisi 02 Desember 2021, Disetujui 02 Desember 2021}

\begin{abstract}
ABSTRAK
Badan Usaha Milik Desa (BUMDesa) dibentuk dengan maksud dan tujuan meningkatkan perekonomian desa dengan cara mengelola potensi produkstif desa sesuai dengan kebutuhan masyarakatnya. BUMDesa diharapkan mampu menjadi penggerak utama ekonomi desa sekaligus mempercepat pemerataan pembangunan di desa. Oleh sebab itu, upaya serius perlu dilakukan oleh pengurus BUMDesa dan Pemerintah Desa agar pengurusan BUMDesa berjalan dengan efektif, efisien, professional, dan mandiri. Melalui mekanisme self help dan member-based, BUMDesa membuka peluang partisipasi masyarakat desa secara keseluruhan dalam mendayagunakan potensi produktif desa. Akan tetapi, pengurus bersama dengan Pemerintah Desa juga perlu menciptakan aturan main bersama dengan stakeholders lainnya agar usaha BUMDesa tidak dikuasai oleh kelompok tertentu di tingkat desa. Sebagai salah satu BUMDesa yang ada di Kabupaten Purworejo, BUMDesa Banjarsari baru mempunyai satu jenis usaha, yaitu penyewaan Gedung. Akan tetapi, pengurusan Gedung sebagai asset produktif milik BUMDesa belum dilakukan dengan baik sebab kemampuan manajerial pengurus BUMDesa Desa Banjarsari Kecamatan Purwodadi belum memadai. Pengurus BUMDesa belum melakukan analisis usaha maupun analisis keuangan dalam menjalankan usahanya tersebut. Kondisi tersebut memotivasiTim pengabdian masyarakaat untuk memberikan pelatihan analisis usaha serta penyusunan laporan keuangan agar usaha yang dikelola BUMDesa Desa Banjarsari dapat berjalan dengan baik, menghasilkan keuntungan, dan berkelanjutan. Pelatihan yang diberikan diharapkan memperkuat kapasitas kelembagaan BUMDesa Desa Banjarsari. Hasil kegiatan pelatihan menunjukkan bahwa pengurus BUMDesa sangat bersemangat dalam mengikuti pelatihan. Hal ini diketahui selama sesi diskusi dan tanya jawab. Peserta yang merupakan pengurus BUMDesa bahkan mengharapkan agar kegiatan pelatihan semacam ini diberikan secara terjadwal dan terprogram agar pengurus benarbenar paham dan kemudian percaya diri dalam mengelola usaha BUMDesanya. Kesimpulan yang diambil di akhir sesi pelatihan, BUMDesa Banjarsari perlu diberikan pendampingan, pelatihan, dan transfer Ipteks pengurusan BUMDesa secara berkesinambungan serta menjalin kemitraan dengan pelaku bisnis lain agar bisnisnya lebih cepat berkembang.
\end{abstract}

Kata kunci: BUMDesa; pengurusan badan usaha; analisis usaha; laporan keuangan

ABSTRACT
Village-Owned Enterprises (VOEs) were formed to improve the village economy by managing the
productive potential of the village by the needs of the community. Therefore, serious efforts need to be
made by the VOEs administrators and the Village Government so that the administrators of VOEs run
effectively, efficiently, professionally, and independently. Through self-help and member-based
mechanisms, VOEs open opportunities for the participation of the village community as a whole in
utilizing the productive potential of the village. However, the administrators along with the Village
Government also need to create rules of the game together with other stakeholders so that the VOEs
business is not controlled by certain groups at the village level. As one of the VOEs in Purworejo
Regency, the VOEs Banjarsari just has one type of business, namely building rentals. However, the
management of the building as a productive asset belonging to VOEs has not been carried out properly
because the managerial capabilities of the VOEs administrators, Banjarsari Village, Purwodadi District
are not yet adequate. The VOEs administrators have not conducted a business analysis or financial
analysis in running the business. The condition motivates the community service team of Universitas
Muhammadiyah Purworejo to provide training in business analysis and preparation of financial reports
for the administrators so that they can run the business well, generate profits, and be sustainable. The
training provided is expected to strengthen the institutional capacity of the Banjarsari village-owned 
enterprise. The results showed that they were very enthusiastic about participating in the training as well as they expect more that such training activities are provided on a scheduled and programmed basis so that they get better to understand and also be confident in managing the business. The findings show that administrators need to be provided with assistance, training, and transfer of science and technology to manage VOE on an ongoing basis and establish partnerships with other business actors so that the business will be able to grow faster.

Keywords: village-owned enterprises; business entity management; business analysis; financial reports

\section{PENDAHULUAN}

Pemerintah desa mempunyai peran strategis dalam pemerataan pembangunan nasional. Peran tersebut saat ini didukung oleh sebuah badan usaha yang berbadan hukum dan dikelola oleh pemerintah desa bersama dengan masyarakat desa yang disebut Badan Usaha Milik Desa (Bumdesa). Badan usaha tersebut juga berperan dalam memperkuat perekonomian desa. Desa yang secara mandiri mampu menyediakan kebutuhan warganya dapat dikatakan mampu menyejahterakan warga sekaligus menghasilkan pendapatan untuk desa itu (Nursyamsu \& Kurniadi, 2020). Desa mandiri mampu memanfaatkan sumberdaya alam maupun sumberdaya manusia produktif yang ada di desa sekaligus mengembangkannya menjadi sumber pendapatan. Suryatimur et al., (2020) menuliskan bahwa BUMDesa menjadi harapan masyarakat desa untuk meningkatkan kesejahteraannya. Berikut ini peran Bumdesa menurut beberapa ahli:

1. penggerak kegiatan ekonomi desa (Suhu et al., 2020);

2. mewujudkan pemerataan pembangunan sehingga ketimpangan antara desa dan kota dapat diperkecil (Sayuti, 2011);

3. membuka lapangan pekerjaan sehingga mengurangi pengangguran di desa (Sinarwati, 2019);

4. mendorong masyarakat memulai usaha baru sesuai potensi yang dimiliki, meningkatkan taraf pendidikan dan kesehatan masyarakat (Caya \& Rahayu, 2019);

5. mengonsolidasi dan mendayagunakan beragam potensi ekonomi sehingga pendapatan asli desa meningkat (Bambang \& Suparno, 2017).

Selain sebagai lembaga komersial yang bertujuan mendapatkan keuntungan guna meningkatkan pendapatan asli desa (PADes), Bumdesa juga merupakan lembaga sosial yang berpihak kepada kepentingan masyarakat melalui kontribusinya dalam penyediaan pelayanan sosial.

Agar Bumdesa sebagai lokomotif pembangunan ekonomi lokal tingkat desa dapat menjalankan fungsinya secara optimal, diperlukan kemampuan manajerial dari para pengurusnya, agar Bumdesa dapat memberikan keuntungan optimal dan digunakan untuk pembangunan desa itu sendiri. Keuntungan yang diperoleh digunakan sebesar-besarnya untuk meningkatkan kesejahteraan masyarakat (Pangemanan \& Jocom, 2019). Dari aspek kepengurusan, Bumdesa sepenuhnya dikelola oleh masyarakat desa, yaitu dari desa, oleh desa, dan untuk desa (Sihabudin., 2019) yang dikelola secara profesional namun tetap bersandar pada potensi asli desa agar usaha yang dijalankan tetap efektif.

Desa Banjarsari Kabupaten Purworejo memiliki potensi sumberdaya alam sebagai sumber pendapatan desa. Saat ini BUMDesa Banjarsari merencanakan memiliki unit usaha Jasa Penyewaan Gedung. Alasan pendirian usaha mengikuti unit usaha yang telah berjalan tanpa melalui pertimbangan dari sisi bisnis. Hal tersebut terjadi karena pengurus BUMDesa belum mengetahui analisis kelayakan usaha, belum mampu menyusun dan belum mengetahui manfaat analisis kelayakan usaha. Lebih lanjut, pengurus juga belum menghitung perkiraan keuntungan, analisis titik impas, dan waktu balik modal yang sebenarnya sangat diperlukan untuk memperkirakan pendapatan yang akan diterima desa. Hal ini disebabkan oleh ketidakmampuan pengurus dalam menyusun laporan usaha secara sistematis yang memuat rencana kegiatan yang akan dilakukan, estimasi pendapatan, biaya, keuntungan, dan jangka waktu pencapaian keuntungan.

Di sisi lain, analisis kelayakan usaha perlu dilakukan untuk mengetahui bahwa usaha yang dilakukan dapat memberikan keuntungan, waktu tercapai titik impas (pulang pokok/Break Event Point/BEP) dan lama waktu pengembalian modal. Analisis kelayakan usaha juga digunakan sebagai alat evaluasi dan pengambilan keputusan bagi Bumdesa yang menggunakan sumber dana dari Anggaran Pendapatan Belanja Desa (APBDes).

Manfaat yang diperoleh dengan melakukan penyusunan analisis kelayakan usaha adalah: 1) mencegah kebangkrutan usaha Bumdesa; dan 2) mencegah Bumdesa 
agar tidak melanggar hukum khususnya Permendagri Nomor 20 Tahun 2018 (Sinarwati et al., 2021).

Lemahnya kemampuan pengurus Bumdesa, dalam hal ini Bumdesa Desa Banjarsari, disebabkan minimnya kemampuan manajerial, penguasaan ilmu bisnis, serta rendahnya kemampuan dalam membangun jejaring unit-nit bisnis. Padahal, semua kemampuan tersebut sangat diperlukan agar peran dan fungsi Bumdesa Desa Banjarsari dapat berjalan optimal.

Hal tersebut sesuai dengan penelitian yang dilakukan (Mayu, 2016) pada Bumdesa Desa Tebih Mandiri yang menunjukkan bahwa faktor utama yang menghambat tumbuh dan berkembangnya Bumdesa adalah kurangnya kemampuan kepemimpinan, manajerial, dan tata kelola. Ketiga hal ini belum berjalan sebagaimana mestinya disebabkan kurangnya kualitas dan kapasitas pengetahuan yang dimiliki direktur dalam mengelola Badan Usaha Milik Desa. Selain itu juga terbatasnya sumber daya manusia, pengetahuan pengurus, belum menerapkan prinsip-prinsip manajemen dan kurangnya pengalaman.

Berdasarkan latar belakang tersebut maka pengurus Bumdesa Banjarsari perlu mendapatkan tambahan pengetahuan dan keterampilan dalam pengurusan usaha sebagai modal dasar dalam mengembangkan Badan Usaha Milik Desa. Pengurus yang mempunyai pengetahuan tentang manajemen dan penguasaan keterampilan teknis bisnis berdampak pada pengelolaan bisnis secara efektif dan efisien.

Busyairi \& Arnila (2021) menjelaskan bahwa meningkatnya pemahaman manajemen, penguasaan keterampilan, pengetahuan teknis terhadap pekerjaan tertentu terbukti berpengaruh positif terhadap pengelolaan Bumdesa secara keseluruhan.

$$
\text { Douglas Cloud (1993:8) dalam }
$$

(Sihabudin, 2019) menjelaskan bahwa kompetensi teknik, kompetensi pemasaran, kompetensi keuangan, dan kompetensi hubungan manusia merupakan kompetensi manajerial yang utama. Sebab, aktivitas di Bumdesa pada prinsipnya sama dengan pengelolaan perusahaan, yang terdiri dari berbagai fungsi bisnis, yaitu: fungsi produksi, fungsi pemasaran, fungsi keuangan, fungsi sumberdaya manusia, serta fungsi sistem informasi manajemen. Agar fungsi tersebut berjalan dengan baik dibutuhkan kemampuan manajerial yang memadai agar tujuan perusahaan tercapai. Dengan demikian dapat dikatakan bahwa kompetensi manajerial menjadi kunci keberhasilan pengurusan Bumdesa.
Berdasarkan latar belakang tersebut, kegiatan pengabdian masyarakat ini dimaksudkan untuk meningkatkan wawasan, pengetahuan, dan keterampilan manajerial dan teknis bisnis pengurus Bumdesa Desa Banjarsari terkait tentang manajemen usaha, analisis usaha, dan penyusunan laporan keuangan. Diharapkan, setelah mengikuti pelatihan ini pengurus mempunyai kemampuan manajerial Bumdesa, kemampuan mengelola usaha, melakukan analisis usaha, dan menyusun laporan keuangan dengan baik sesuai dengan standar.

\section{METODE}

Pengabdian masyarakat di Bumdesa Desa Banjarsari dilaksanakan menggunakan metode penyuluhan dan pelatihan secara luring di Balai Desa Banjarsari dan dihadiri seluruh pengurus. Penyuluhan dilakukan dengan pemaparan materi oleh narasumber dan membagikan materi kepada peserta agar diskusi lebih lancar dan peserta lebih mudah dalam memahami materi. Setelah paparan selesai dilanjutkan diskusi dan pelatihan menyusun analisis usaha dan laporan keuangan. Jumlah peserta 10 orang dengan tingkat pendidikan lulus Sekolah Menengah Umum/Kejuruan. Dari aspek usaia, pengurus termasuk dalam usia produktif, dengan jenis kelamin 6 orang laki-laki dan 4 orang perempuan.

Kegiatan dilaksanakan melalui empat tahapan sebagai berikut.

1. Tahap Persiapan Penyuluhan dan Pelatihan

a. Survei dan Koordinasi dengan Dinas Pemberdayaan Masyarakat dan Desa (Dispermades) Kabupaten Purworejo, Kepala Desa, dan pengurus Bumdesa.

b. Observasi dan identifikasi masalah yang dihadapi dalam pengurusan Bumdesa.

c. Membentuk tim pengabdian masyarakat.

d. Mengurus perizinan.

\section{Tahap Pelaksanaan Penyuluhan dan} Pelatihan

Penyuluhan dan pelatihan dilakukan secara luring. Tahapanya:

a. Narasumber memaparkan materi.

b. Diskusi dan Tanya Jawab.

c. Pelatihan menyusun analisis usaha dan penyusunan laporan keuangan.

d. Praktek menyusun analisis usaha dan menyusun laporan keuangan dari bisnis yang dijalankan.

Target luaran Tahap 2 ini adalah bertambahnya wawasan, pengetahuan, 
dan keterampilan teknis pengurus Bumdesa tentang analisis usaha.

\section{Tahap Evaluasi}

Kegiatan evaluasi dilakukan setelah kegiatan pelatihan selesai. Evaluasi dilakukan dengan menganalisis keaktifan peserta pada saat diskusi dan praktek. Kegiatan evaluasi bertujuan untuk mengetahui apakah transfer ilmu berjalan dengan lancar dan pengurus BUMDesa dapat menerima dan memahami materi dengan baik. Teknik evaluasi yang digunakan adalah observasi (pengamatan) dan tanya jawab langsung kepada peserta.

\section{Tahap Penyusunan Laporan}

Pada tahap ini tim menyusun laporan hasil pengabdian masyarakat sebagai tahap akhir kegiatan.

\section{HASIL DAN PEMBAHASAN}

\section{Tahap Koordinasi dan Persiapan} Penyuluhan

Tahap koordinasi dan persiapan kegiatan, Tim Pengabdian Masyarakat berkoordinasi dengan Dispermades Kabupaten Purworejo untuk memastikan jadwal kegiatan dan bentuk kegiatan yang dilakukan. Hal ini dilakukan mengingat BUMDesa berada dalam pembinaan Dispermades.

Pengurus BUMDesa Banjarsari dengan usia muda memiliki motivasi tinggi untuk maju dan menambah pengetahuan terkait dalam pengurusan usaha BUMDesa. Pengurus BUMDesa sangat awam terhadap manajemen usaha dan pengurusan bisnis sehingga adanya pelatihan dan pendampingan yang dilakukan oleh Tim Pengabdian Masyarakat Universitas Muhammadiyah Purworejo merasa sangat diharapkan oleh peserta.

Tahap persiapan, Tim Pengabdian Masyarakat melakukan survei pendahuluan dan mencari informasi terkait kebutuhan masyarakat sasaran. Hasil survei pendahuluan diperoleh data bahwa secara umum pengurus BUMDesa Banjarsari belum mengetahui secara mendalam terkait manajemen usaha, analisis kelayakan usaha dan penyusunan laporan keuangan.

Selain itu juga diketahui bahwa pengurus BUMDesa Banjarsari masih lemah dalam penerapan ilmu bisnis untuk pengurusan usaha. Bahkan kemampuan menyusun laporan keuangan masih sangat lemah. Pengurusan bisnis masih konvensional dan pola berpikir pengurus masih sederhana. Unit usaha yang akan dibangun adalah Penyewaan Gedung, dan mereka berpikir karena awal usaha maka yang penting pemasukan dan pengeluaran dicatat rapi dan selanjutnya dihitung apakah usaha mendapatkan keuntungan atau mengalami kerugian.

Berdasarkan informasi tersebut maka kegiatan pengabdian masyarakat ini difokuskan pada peningkatan pengetahuan dan kemampuan pengurus BUMDesa Banjarsari dalam manajemen usaha Penyewaan Gedung dan analisis bisnis yang dijalankan. Adanya kegiatan pengabdian masyarakat ini diharapkan dapat menambah wawasan keilmuan dan merubah mindset atau cara berpikir dalam mengelola bisnis Penyewaan Gedung.

\section{Tahap Pelaksanaan Penyuluhan dan Pelatihan}

Berdasarkan hasil survei pendahuluan maka Tim Pengabdian Kepada Masyarakat Universitas Muhammadiyah Purworejo memberikan pelatihan dengan tema "Analisis Usaha BUMDesa". Berdasarkan tema tersebut maka materi penyuluhan dan pelatihan yang diberikan adalah:

1. Manajemen Usaha untuk Unit Usaha Penyewaan Gedung

2. Analisis Kelayakan Usaha Penyewaan Gedung

3. Penyusunan Laporan Keuangan Unit Usaha Penyewaan Gedung

Tahapan kegiatan dimulai dengan pembukaan, paparan materi oleh narasumber, praktik menyusun analisis usaha dan laporan keuangan, diskusi, serta terakhir penutup. Penyuluhan dilaksanakan secara luring di balai desa Banjarsari. Pemahaman materi agar lebih cepat maka materi dibagikan sebelum paparan materi. Tujuannya agar pengurus sudah membaca materi terlebih dahulu, sehingga transfer ipteks dapat berjalan lancar dan lebih maksimal. Materi apabila ada yang belum jelas maka pengurus segera mengajukan pertanyaan.

Berdasarkan pengamatan pada saat penyuluhan diketahui bahwa pengurus betulbetul awam dengan analisis kelayakan usaha dan penyusunan laporan keuangan yang sistematis. Kemampuan dalam menjalankan bisnis baru sebatas menetapkan harga sewa, penghitungan biaya dan keuntungan. Sedangkan kemampuan terkait bagaimana menghitung titik impas, kapan titik balik modal, dan bagaimana menggerakkan orang-orang agar dapat bekerja untuk mencapai tujuan usaha masih lemah.

Pola berpikir pimpinan/manager Bumdesa masih sangat sederhana, yaitu gedung segera dibangun, disewakan dan mampu memberikan hasil untuk pendapatan desa. Bendahara yang bertugas mengelola keuangan dan menyusun laporan keuangan masih memerlukan pelatihan lebih lanjut agar 
mampu menyusun neraca dan laporan rugilaba serta mampu memahami arti dari laporan keuangan tersebut. Bendahara diharapkan juga mampu menggunakan laporan keuangan sebagai alat analisis dan evaluasi untuk mengembangkan bisnis di masa depan.

Pengurus Bumdesa Desa Banjarsari setelah mendengarkan materi yang disampaikan narasumber akhirnya terbuka wawasan keilmuan dan pengetahuannya dalam pengurusan bisnis. Pengurus Bumdesa menyadari bahwa mereka harus mempunyai kemampuan ilmu dan teknis bisnis dengan baik agar usaha yang dijalankan dapat menghasilkan keuntungan optimal. Pengurus Bumdesa sangat antusias pada saat diskusi, dan banyak mengajukan pertanyaan yang kepada narasumber.

Berikut ini hasil diskusi dan tanya jawab narasumber dengan Pengurus Bumdesa Banjarsari.

Tabel 1. Pertanyaan Pengurus Bumdesa kepada Narasumber

\begin{tabular}{ll}
\hline No. & \multicolumn{3}{c}{ Pertanyaan } \\
\hline 1. & $\begin{array}{l}\text { Bagaimanakah memotivasi dan } \\
\text { menggerakkan pengurus agar lebih } \\
\text { bersemangat menjalankan tugas yang } \\
\text { diberikan dalam mengembangkan unit } \\
\text { usaha Bumdesa? }\end{array}$ \\
\hline 2. & $\begin{array}{l}\text { Bagaimanakah mengelola modal } \\
\text { usaha untuk pengembangan bisnis ke } \\
\text { depan? }\end{array}$ \\
\hline 3. & $\begin{array}{l}\text { Bagaimanakah menghitung titik impas } \\
\text { agar usaha penyewaan gedung tidak } \\
\text { rugi? }\end{array}$ \\
\hline Bagaimana menyusun laporan \\
keuangan yang sederhana bagi \\
pengurus Bumdesa yang masih \\
pemula ini? \\
Saran: Sebaiknya kegiatan penyuluhan \\
dan pelatihan tidak hanya satu kali \\
tetapi beberapa kali agar pengurus \\
semakin mahir dalam mengelola bisnis \\
dan menyusun laporan keuangan.
\end{tabular}

Sumber: Data Primer Diolah (2021)

Tabel 1 menginformasikan bahwa pengurus Bumdesa Desa Banjarsari sangat antusias dan termotivasi dalam pengurusan usaha BUMDesa. Apabila dilihat dari pengetahuan yang dimiliki Pengurus maka mereka memerlukan pendampingan agar transfer ilmu dapat berjalan dengan baik Masyarakat menyadari potensi alam yang dimiliki, tetapi terbatas dalam penguasaan teknologi. Pembahasan setiap pertanyaan pengurus BUMDesa dijelaskan sebagai berikut.

Cara memotivasi pengurus agar lebih bersemangat menjalankan tugas dapat dilakukan dengan memberikan pemahaman kepada pengurus bahwa kemajuan usaha BUMDesa akan memberikan dampak pada peningkatan kesejahteraan masyarakat. Unit usaha BUMDesa adalah sumber pendapatan desa yang dapat digunakan secara maksimal untuk pembangunan desa. Usaha Penyewaan Gedung memerlukan kerjasama semua pihak sehingga perlu kesadaran dan kesungguhan dalam mengelola usaha secara profesional.

Usaha penyewaan gedung apabila sudah mapan dan berkembang maka BUMDesa dapat memberikan gaji yang layak kepada pengurus. Adanya gaji yang layak akan memotivasi pengurus bekerja secara maksimal. Gaji merupakan faktor yang menentukan seseorang memiliki motivasi tinggi untuk bekerja. Gaji yang terlalu rendah menyebabkan seseorang memiliki kinerja rendah bahkan memilih mengundurkan diri dari pekerjaan.

Menurut (Filya, 2018) bahwa kebanyakan warga desa tidak tertarik untuk menjadi pengurus Bumdesa karena alas an honor/gaji yang rendah sehingga mereka lebih memilih pekerjaan lain yang memberikan imbalan lebih besar.

Kondisi tersebut sejalan dengan dengan hasil penelitian yang dilakukan oleh (Sukidi \& Wajdi, 2016) yang menunjukkan bahwa motivasi dan kompensasi merupakan dua faktor penting terhadap kepuasan kerja dan kinerja pegawai. Keduanya secara simultan mempengaruhi kepuasan kerja sedangkan motivasi, kompensasi, dan kepuasan kerja berpengaruh terhadap kinerja pegawai. Kamal \& Widianti (2016) menemukan bahwa gaji mempengaruhi tinggi rendahnya motivasi kerja. Semakin besar gaji yang diberikan, semakin tinggi motivasi karyawan dalam bekerja.

Dengan memperhatikan hasil-hasil penelitian tersebut, pengurus Bumdesa Banjarsari harus memperhatikan pemberian gaji kepada karyawan agar motivasi dan kinerja tinggi sehingga mereka bekerja secara optimal. Keberlanjutan usaha juga didukung oleh pengurusan modal usaha yang baik. Modal usaha BUMDesa Desa Banjarsari berasal dari Pendapatan Asli Desa sehingga ada sebagian keuntungan yang diserahkan untuk kas desa. Pendapatan bersih untuk biaya operasional usaha dan cadangan modal harus betul-betul dihitung secara cermat. Hal ini sesuai dengan pertanyaan salah satu pengurus BUMDesa Banjarsari, bagaimana mengelola modal usaha untuk pengembangan bisnis.

Agar bisnis dapat menghasilkan keuntungan, pemahaman tentang aturan pengeloaan administrasi keuangan dan teknis pengurusan \& pengadminsitrasian keuangan dalam Bumdesa, mulai dari proses perencanaan, proses produksi, hingga 
dihasilkan produk. Termasuk didalamnya kemampuan dalam melakukan perencanaan anggaran atas biaya-biaya yang dibutuhkan dalam pengurusan Bumdesa. Pengurus Bumdesa Desa Banjarsari harus memahami tentang cash flow, perputaran modal, perkembangan aset, dan untung \& rugi dalam menjalankan usaha bisnisnya (penyewaan Gedung) sekaligus mengelolanya dengan tepat.

Terkait dengan usaha penyewaan Gedung oleh Bumdesa Desa Banjarsari, hal penting yang wajib diperhatikan terkait Gedung adalah kondisi fisik Gedung (seperti: luas Gedung dan kapasitas Gedung), fasilitasfasilitas pendukung (seperti: perkakas pesta/pertemuan, koneksi internet, air bersih, tempat parkir, pengelolaan limbah pasca pesta/rapat), biaya-biaya tetap dan overhead yang timbul dari asset tetap berupa gedung (seperti: biaya pemeliharaan, depresiasi, biaya listrik, koneksi internet), dan kemungkinan ekspansi gedung atau bisnis penyewaan (seperti: penyewaan traktor, penyewaan tenda, penyewaan mobil, penyewaan meja/kursi, dll.). Sebagai sebuah badan usaha komersial, Bumdesa mempunyai kewajiban untuk mengelola keuangan dengan baik dan benar. Bumdesa harus melakukan perencanaan keuangan dan analisis kelayakan usaha (dari aspek keuangan) untuk setiap bisnis yang dilakukan. Pengelolaan aspek keuangan yang dilakukan dengan baik dapat menjadi alat untuk meyakinkan para investor potensial.

Secara prinsip, pengelolaan keuangan Bumdesa tidak berbeda dengan pengelolaan keuangan jenis badan usaha lain. Semua kegiatan transaksi yang dilakukan harus dicatat pada buku-buku tertentu sesuai jenisnya. Pembukuan yang dilakukan dengan baik dapat membantu pengurus Bumdesa mengetahui dan mengidentifikasi faktor-faktor yang menyebabkan usaha itu mengalami untung atau rugi. Pembukuan yang baik juga membantu pengurus untuk dapat meminimalisir pengeluaran serta lebih tertib dan disiplin dalam menggunakan anggaran.

Selanjutnya terkait berapa besarnya keuntungan yang akan diterima dan titik impas maka pengurus BUMDesa Banjarsari harus menghitung dengan teliti biaya investasi pembangunan gedung, biaya tetap, biaya variabel, dan tarif sewa gedung. Hal ini penting karena tarif sewa gedung menentukan titik impas usaha.

Karena besarnya keuntungan yang diperoleh dari penyewaan gedung tergantung pada penetapan tarif sewa yang tepat dan banyaknya orang yang menyewa, Pengurus harus menetapkan strategi pemasaran yang efektif. BUMDesa Banjarsari dapat menggunakan Teknik tertentu untuk meningkatkan jumlah penjualan, seperti: menggunakan platform media social (medsos), memanfaatkan konten, memanfaatkan influencer, atau membuka program afiliasi.

Promosi merupakan kegiatan pemasaran yang sangat penting terutama untuk memperkenalkan produk baru kepada masyarakat. Cateora \& Graham (2007) menjelaskan bahwa promosi merupakan kegiatan pemasaran yang mempengaruhi dan mendorong konsumen untuk melakukan pembelian maupun pembelian ulang. Tjiptono (2015) menuliskan bahwa tujuan promosi adalah menginformasikan, membujuk dan mengingatkan. Usaha penyewaan gedung karena masih baru maka tujuan promosi adalah menginformasikan kepada masyarakat dan membujuk mereka agar menggunakan gedung tersebut.

Hal ini sejalan dengan hasil penelitian Wijayanti \& Handayani (2015) yang menunjukkan bahwa lokasi, harga, kualitas, dan promosi mempengaruhi menurut keputusan pembelian rumah. Kemudian, menurut (Wardhani et al., 2015) pembelian juga dipengaruhi oleh persepsi konsumen terkait dengan citra pengembang, produk, dan fasilita.

Oleh sebab itu, apabila Bumdesa Desa Banjarsari menginginkan usaha penyewaan gedung laku, pengurus harus melakukan promosi, membangun gedung dengan kualitas bagus serta fasilitas yang lengkap. Lokasi gedung harus strategis dan harga sewa cukup terjangkau. Citra Bumdesa Desa Banjarsari harus dibangun dibenak masyarakat sehingga masyarakat percaya terhadap kualitas gedung yang dimiliki Bumdesa.

Pembahasan lebih lanjut adalah analisis BEP. Pengurus Bumdesa sebelum menghitung BEP harus membuat rincian biaya dan harga sewa gedung. Data yang telah tersusun selanjutnya digunakan untuk menghitung BEP unit, BEP harga, dan BEP penjualan. Apabila Bumdesa akan merencanakan besarnya keuntungan yang diinginkan maka harus dihitung contribution margin. Pelatihan menghitung BEP mengalami kendala karena Pengurus belum menyusun biaya investasi, harga sewa gedung, dan biaya operasional. Praktik menghitung BEP akhirnya menggunakan angka ilustrasi (studi kasus berdasarkan pustaka).

Dengan melakukan analisis BEP pengurus akan dapat dapat menganalisis dan mengevaluasi bisnis. Utari et al., (2016) dan Ravelly (2016) dalam (Maulidin et al., 2020) mengatakan bahwa BEP dapat digunakan sebagai salah satu cara untuk membuat 
perencanaan laba. Selain itu, analisis BEP dapat digunakan untuk membuat perencanaan, pengendalian, dan pengambilan keputusan untuk menghasilkan laba. Analisis BEP juga dapat digunakan untuk mengantisipasi perubahan yang terjadi pada harga jual ataupun biaya.

Tingkat break even point agar lebih rendah dan mencapai laba yang diinginkan, dapat dilakukan dengan menekan biaya tetap, biaya variabel, dan meningkatkan volume penjualan (Jubaedah, 2020).

Pengurus Bumdesa selanjutnya harus mengetahui dan memahami penyusunan laporan keuangan. Pertanyaan yang disampaikan pengurus Bumdesa adalah bagaimana menyusun laporan keuangan yang sederhana bagi Bumdesa Pemula. Pertanyaan ini muncul mengingat pengurus Bumdesa sangat awam terhadap laporan keuangan. Pengurus dalam menghitung biaya, dan keuntungan sudah bisa, namun laporan keuangan masih sangat sederhana. Pengurus baru bisa menyusun buku kas. Buku kas ini digunakan untuk mengetahui posisi kas saat ini dan berapa besar keuntungan yang diperoleh.

Sebelum memberikan pelatihan, Tim pengabdian masyarakat Universitas Muhammadiyah Purworejo terlebih dahulu menjelaskan secara detil mengenai:

1. Aspek Kewirausahaan (bagaimana memulai usaha, langkah-langkah menjalankan bisnis baru, merintis bisnis baru, menentukan bidang usaha, bentuk kepemilikan, organisasi yang akan digunakan, penentuan tempat usaha, dan lingkungan usaha baik mikro maupun makro).

2. Aspek Keuangan (pembukuan usaha, komponen pembukuan, cara menyusun pembukuan, dan buku apa saja yang harus disiapkan untuk pencatatan keuangan). Pencatatan harus dilakukan secara teratur setiap hari, dan selanjutnya disusun laporan triwulan, enam bulan dan akhirnya akhir tahun. Laporan akhir tahun berupa neraca, laporan rugi-laba da perubahan modal.

3. Aspek Pemasaran (segmen pasar, Analisa pasar, Analisa kompetitor, diferensiasi dan keunggulan produk, dan promosi).

\footnotetext{
Pada kesempatan tersebut, narasumber memberikan pelatihan penyusunan laporan keuangan menggunakan software excel yang praktis dan sederhana. Software tersebut dapat digunakan oleh Pengurus Bumdesa Desa Banjarsari untuk mencatat transaksi penjualan dan menyusun
}

laporan keuangan. Pengurus dilatih menggunakan aplikasi tersebut. Namun karena pengurus tidak membawa laptop, praktek penyusunan laporan keuangan dilakukan secara manual menggunakan kertas.

Pengurus Bumdesa sangat antusias mengikuti penyuluhan dan pelatihan. Pengurus meminta agar pelatihan penyusunan laporan keuangan bisa diberikan beberapa kali sehingga mereka betul-betul memahami laporan keuangan dan manfaatnya. Pengurus juga menyadari bahwa kemampuan bisnis mereka masih kurang sehingga penyuluhan dan pelatihan sangat mereka harapkan.

Berikut adalah dokumentasi kegiatan penyuluhan dan pelatihan pada Pengurus BUMDesa Desa Banjarsari.

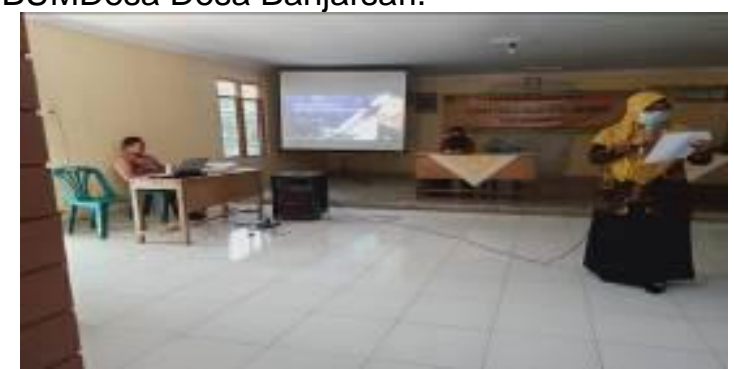

Gambar 1. Khalayak Sasaran Mengikuti

Penyuluhan Manajemen Usaha BUMDesa

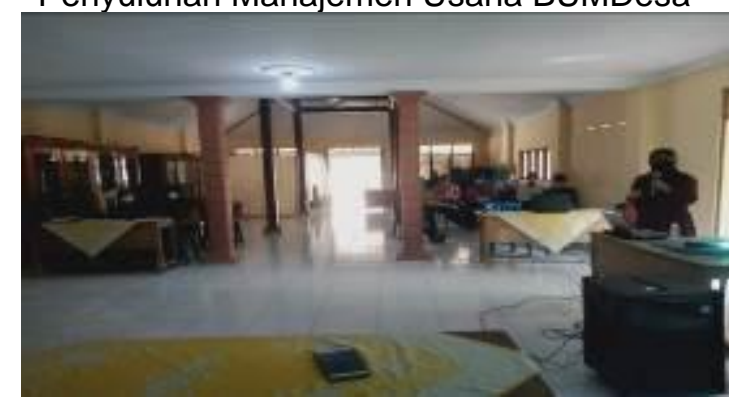

Gambar 2. Khalayak Sasaran Mengikuti Pelatihan Penyusunan Laporan Keuangan

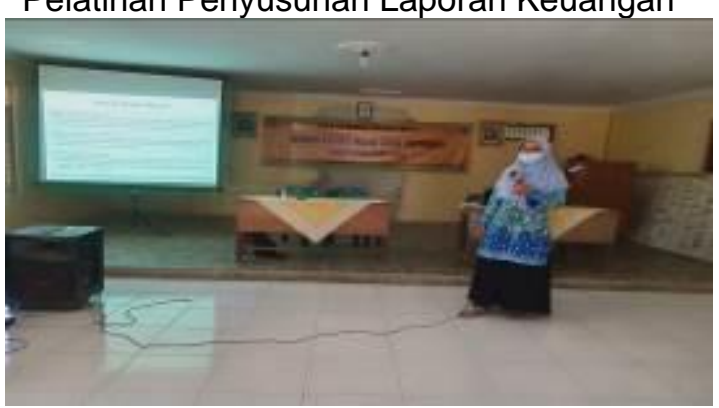

Gambar 3. Khalayak Sasaran Mengikuti Pelatihan Analisis Usaha 


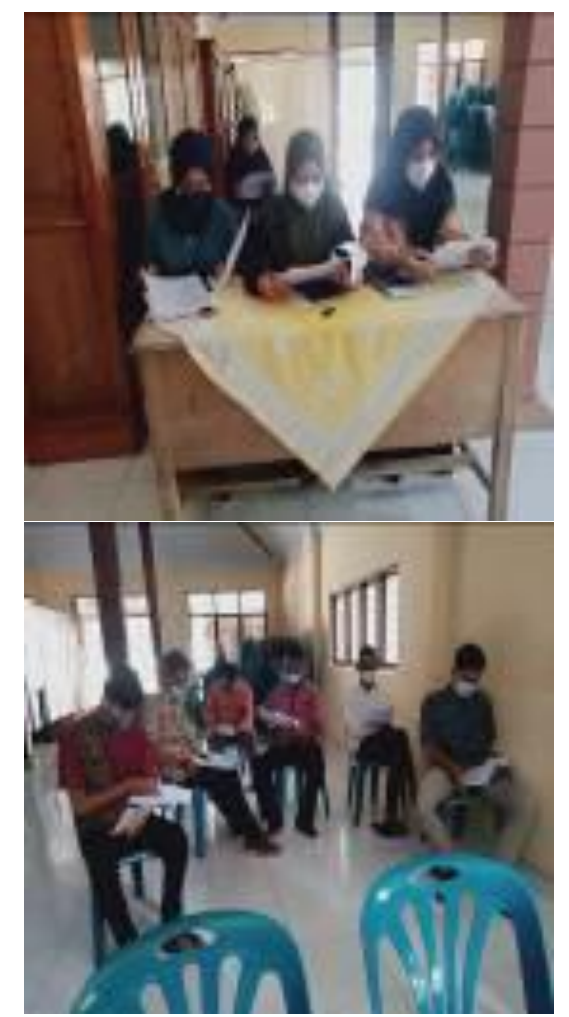

Gambar 4. Praktik Analisis Usaha dan Penyusunan Laporan Keuangan

\section{Tahap Evaluasi}

Evaluasi dilakukan setelah kegiatan penyuluhan dan pelatihan dilakukan. Evaluasi dimaksudkan untuk mengetahui tingkat keberhasilan kegiatan yang dilakukan oleh tim pengabdian masyarakat. Evaluasi dilakukan dengan mengamati jalannya diskusi dan antusias masyarakat sasaran terhadap materi yang diberikan. Semangat dan motivasi pengurus Bumdesa dalam mengikuti kegiatan pelatihan cukup tinggi. Hal ini teridentifikasi dari banyaknya pertanyaan yang diajukan terkait materi yang diberikan.

\section{Tahap Penyusunan Laporan}

Laporan kegiatan dilakukan sebagai bentuk pertanggungjawaban Tim Pengabdian Masyarakat kepada Lembaga Penelitian dan Pengabdian Masyarakat (LPPM) Universitas Muhammadiyah Purworejo dan Dispermades Kabupaten Purworejo yang telah memberikan fasilitas dan hibah pendanaan.

\section{SIMPULAN DAN SARAN}

Simpulan yang dapat disampaikan dari kegiatan penyuluhan dan pelatihan oleh Tim pengabdian kepada masyarakat ini adalah tingginya semangat dan motivasi dari pengurus Bumdesa Desa Banjarsari untuk menerapkan ilmu bisnis dalam pengurusan unit usaha Bumdesa, yaitu Penyewaan Gedung. Untuk meningkatkan kemampuan dan keterampilan pengurus BUMDesa perlu dilakukan pendampingan dan pelatihan yang berkelanjutan sehingga pengurus benar-benar mampu menerapkan ilmu bisnis dalam mengelola usaha penyewaan gedung. Pengurus memerlukan pedampingan intensif dalam penyusunan laporan keuangan dan analisis usaha agar dapat merencanakan pengembangan usaha dimasa depan.

Saran untuk keberlanjutan usaha adalah perlu dilakukan pendampingan, pelatihan dan transfer ipteks yang berkelanjutan. Perlu sinergi dan kerjasama antara Perangkat Desa dan Pengurus BUMDesa dalam mengembangkan usaha penyewaan gedung. Pendampingan agar efektif sebaiknya melibatkan narasumber dari berbagai disiplin ilmu, dan menjalin kemitraan dengan pelaku bisnis yang lain agar unit usaha BUMDesa cepat besar dan maju.

\section{UCAPAN TERIMAKASIH}

Kami selaku Tim Pengabdian Masyarakat di Bumdesa Desa Banjarsari Kecamatan Purwodadi Kabupaten Purworejo mengucapkan terima kasih yang tak terhingga kepada Dinas Pemberdayaan Masyarakat Desa (Dispermasdes), LPPM Universitas Muhammadiyah Purworejo yang telah memberikan hibah pendanaan dalam pelaksanaan kegiatan ini, serta Pengurus Bumdesa Desa Banjarsari yang telah menyediakan fasilitas kegiatan pengabdian masyarakat dengan semangat yang tinggi untuk maju. Ucapan terima kasih juga kepada semua pihak yang telah membantu terlaksananya kegiatan pengabdian masyarakat. Semoga kegiatan pengabdian ini memberikan manfaat kepada masyarakat.

\section{DAFTAR RUJUKAN}

Bambang, \& Suparno, C. (2017). Model Analisis Kelayakan Usaha Bumdes Di Kecamatan Kaligondang. Prosiding Seminar Nasional Dan Call for Papers "Pengembangan Sumber Daya Perdesaan Dan Kearifan Lokal Berkelanjutan VII" Model Analisis Kelayakan Usaha Bumdes Di Kecamatan Kaligondang, 5(November), 960-964. http://jurnal.Ippm.unsoed.ac.id/ojs/index.p $\mathrm{hp} /$ Prosiding/article/viewFile/533/422

Busyairi, A., \& Arnila, R. A. (2021). Pelatihan Manajemen Usaha Bagi Pengurus BUMDES Sinar Sejahtera Desa Sepit Kecamatan Keruak Kabupaten Lombik Timur. Jurnal ABDIMAS RINJANI, 1(1), 12-25.

https://jurnal.ugr.ac.id/index.php/abr/issu e/view/27

Cateora, \& Graham. (2007). Pemasaran Internasional. Penerbit Salemba Empat. 
Caya, M. F. N., \& Rahayu, E. (2019). Dampak Bumdes Terhadap Kesejahteraan Masyarakat Di Desa Aik Batu Buding, Kabupaten Belitung, Provinsi Bangka Belitung. Jurnal IImu Kesejahteraan Sosial, 20(April), 1-12. http://jurnalkesos.ui.ac.id/index.php/jiks/is sue/view/18

Filya, A. R. (2018). Optimalisasi Pengelolaan Badan Usaha Milik Desa (Bumdes) Dalam Meningkatkan Pades di Kecamatan Bojonegoro Kabupaten Bojonegoro Provinsi Jawa Timur. Jurnal Ekonomi Dan Keuangan Publik, 5(1), 1939.

http://ejournal.ipdn.ac.id/JEKP/article/vie w/393

Jubaedah, E. (2020). Analisis Break Even Point Dalam Perencanaan Laba ( Studi Kasus PT Dirgantara Indonesia ). Indept, Vol. 9, No.1 Februari - Mei 2020, 9(1), 45-51.

Kamal, B., \& Widianti, H. (2016). Pengaruh Gaji Terhadap Motivasi Kerja Karyawan pada SPBN (Stasiun Pengisian Bahan Bakar Nelayan) Karya Mina Kota Tegal. Journal Research Accounting Politeknik Tegal, 5(2), 177-184.

Kartika Pradana Suryatimur, Khotijah, S. A., \& Panji Kusuma Prasetyanto. (2020). Pelatihan Penyusunan Laporan Keuangan pada BUMDes Desa Balesari. Jurnal Pengabdian UntukMu NegeRI, 4(2), 242-246.

https://doi.org/10.37859/jpumri.v4i2.2163

Maulidin, M. Y. G., Indrawan, A., \& Sudarma, A. (2020). Analisis Break Even Point Sebagai Alat Profit Planning Pada Hotel Wijaya Sukabumi. COSTING: Journal of Economic, Business and Accounting, 4(1), 306-316.

https://journal.ipm2kpe.or.id/index.php/C OSTING/issue/view/150

Mayu, W. I. (2016). Faktor-Faktor Yang Menghambat Tumbuh Dan Berkembangnya Badan Usaha Milik Desa Di Desa Pematang Tebih Kecamatan Ujung Batu Kabupaten Rokan Hulu Tahun 2014-2015. JOM FISIP, 3(2), 1-11. www.neliti.com

Ni Kadek Sinarwati, A. M. (2019). The Role of Village Own Enterprises to Rural Development. South East Asia Journal of Contemporary Business, Economics and Law. The Role of Village Own Enterprises to Rural Development. South East Asia Journal of Contemporary Business, Economics and Law, 18(5), 77-83. https://seajbel.com/wpcontent/uploads/2019/04/seajbel5VOL18_227.pdf
Nursyamsu, R., \& Kurniadi, E. (2020). Pelatihan Peningkatan Pengelolaan Badan Usaha Milik Desa (Bumdes) Desa Cibinuang Kabupaten Kuningan. Empowerment: Jurnal Pengabdian Masyarakat, 3(02), 135.

https://doi.org/10.25134/empowerment.v3 i02.4014

Pangemanan, L. R. J., \& Jocom, S. G. (2019). Penyuluhan Sistem Administrasi Badan Usaha Milik Desa Dan Pelatihan Akuntansi BUMDES Di Kecamatan Kauditan kabupaten Minahasa Utara. EDUPRENEUR: Jurnal Pengabdian Kepada Masyarakat Bidang Kewirausahaan, 2(3), 31-38.

Sayuti, H. M. (2011). Pelembagaan Badan Usaha Milik Desa (BUMDES) Sebagai Penggerak Potensi Ekonomi Desa Dalam Upaya Pengentasan Kemiskinan di Kabupaten Donggala. Jurnal Academia, 3(2), 717-728.

Sihabudin. (2019). Pengaruh Kompetensi Manajerial, Kemitraan Usaha dan Jiwa Kewiraushaan Terhadap Pengurusan Dana Serta Implikasinya pada Kinerja Keuangan. (Survey Pada BUMDes di Jawa Barat Yang Terdaftar Di Kementrian Desa, Pembangunan Daerah Tertinggal dan http://repository.unpas.ac.id

Sinarwati, N. K., Herawati, N. T., Telagawati, N. L. W. S., Sapitri, S. A. D., \& Wasuka, I. K. B. P. (2021). Penyusunan Analisis Kelayakan Unit Usaha BUMDES Di Desa Antiga Kelod. Proceeding Senadimas Undiksha, 54-64. https://lppm.undiksha.ac.id/senadimas20 21/

Suhu, B. La, Raoda M. Djae, \& Sosoda, A. (2020). Analisis Pengelola Badan Usaha Milik Desa (BUMDES) Di Desa Geti Baru Kecamatan Bacan Barat Utara Kabupaten Halmahera Selatan. Jurnal Government of Archipelago, I(1), 1-7. file:///C:/Users/Personal/Downloads/KINE RJA PANITIA KHUSUS DEWAN PERWAKILAN RAKYAT DAERAH.pdf

Sukidi, S., \& Wajdi, F. (2016). Pengaruh Motivasi, Kompensasi, Dan Kepuasan Kerja Terhadap Kinerja Pegawai Dengan Kepuasan Kerja Sebagai Variabel Intervening. DAYA SAING Jurnal Ekonomi Manajemen Sumber Daya, 18(2), 79. https://doi.org/10.23917/dayasaing.v18i2. 4505

Tjiptono, F. (2015). Strategi Pemasaran. Penerbit ANDI.

Wardhani, W., Sumarwan, U., \& Yuliati, L. N. (2015). Pengaruh Persepsi dan Preferensi 
Konsumen terhadap Keputusan Pembelian Hunian Green Product. Jurnal Manajemen Dan Organisasi, 6(1), 45-63. https://doi.org/10.29244/jmo.v6i1.12183

Wijayanti, H., \& Handayani, C. M. S. (2015). Pengaruh Lokasi, Harga, Kualitas Produk, Dan Promosi Terhadap Keputusan Pembelian Rumah Surodinawan Grandsite Pada Pt.Dwi Mulya Jaya Mojokerto. Majalah Ekonomi, 20(1), 109123. 